\title{
Genetic Diversity Analysis of Labeo rohita (Hamilton, 1822) Collected from Two Zones of River Ganga Using Microsatellite DNA Markers
}

\author{
Deepak Joshi ${ }^{*}$, Pushpa Lohni ${ }^{2}$ and R.N. $\operatorname{Ram}^{1}$ \\ ${ }^{1}$ Department of Fisheries Resource Management, College of Fisheries, G. B. Pant University of \\ Agriculture and Technology, Pantnagar, India \\ ${ }^{2}$ Department of Molecular Biology and Generic Engineering, College of Basic Science and \\ Humanities, G. B. Pant University of Agriculture and Technology, Pantnagar, India \\ *Corresponding author
}

\section{A B S T R A C T}

The present study was conducted to investigate the level of polymorphism and genetic diversity in natural population of Labeo rohita collected from selected zones of River Ganga using microsatellite DNA markers. 5 primers out of 10 produced amplicons and were selected for primary screening and further genetic analysis of the population. On the basis of the values of Average Nei's Genetic Diversity, observed and expected heterozygosity, fixation index, Shannon's information index obtained through microsatellite marker technique, the present study is the indicative of the fact that the stock of $L$. rohita of Haridwar region of River Ganga is more genetically diverse and genetically differentiated as compared to the stock of Kanpur region as these sites are distantly located and having negligible chance of exchange of gene pool with each other which is responsible for weak sub-structuring of stocks. Genetic variation observed between the two riverine sites may also be caused due to high level of anthropogenic activities in Kanpur region thereby causing blockage of fish movement as well destruction of breeding grounds thus hampering the proper mating within the population and also reducing effective population size.

\section{Introduction}

Of all the plants and animals in the aquatic environment, fish is the most important food source for humans. It constitutes the main part of the diet in many cultures and is also a major source of dietary protein for many communities living in the coastal belt or near some other water sources like rivers, lakes, reservoirs, etc. Along with rich content of protein, fishes are also a good source of PUFAs (Poly Unsaturated Fatty Acids) like $\omega-3$. Labeo rohita, commonly known as rohu in India, is a popular table fish in South and
South-East Asian countries especially India, Bangladesh, Myanmar and Pakistan (Talwar and Jhingran, 1991). It not only provide a significant portion of the protein available for human consumption, but also it is an economically significant activity, providing jobs and investment opportunities to a large mass of people who are directly or indirectly linked with this field in form of trade or tourism. Most of the fishes used for human consumptions are obtained through exploitation of wild populations and with the 
increasing level of exploitation, there has been a need for proper management of these populations. The management of the wild populations comprising commercial or sport fisheries presents various problems in front of us. This necessitates the proper evaluation of genetic stock that will greatly assist in creating base population which can help in elucidating the genetic differences among wild populations Genetic monitoring of a species is essential for the proper management of genetic variability and identification of population groups with independent evolutionary histories. The level of genetic diversity has significant implications for the management and conservation of species. Genetic diversity develops the ability in species and population to maintain and protect themselves against extinction (Ashley, et al., 2003). It also provides the foundation for survival in ever changing environment (Banerjee, et al., 2008). Loss of genetic diversity leads to the fixation of genes, loss of fitness in terms of fecundity, viability, vigour, resistance against diseases and may lead to extinction of local population eventually. Therefore, understanding of genetic variability would be of immense help for setting up of genetic enhancement programmes, effective management and conservation of natural genetic resources.

According to Swaminathan (1984), conservation of genetic stocks is considerable as the genetic diversity is the outcome of thousands of years of evolutionary process. In fisheries biology, the detection of genetic variation among individuals is achieved by the applications of molecular markers. Molecular markers are powerful tools for the analysis of genetic biodiversity, which are based on DNA sequence polymorphisms. A molecular marker (identified as genetic marker) is a fragment of DNA that is associated with a certain location and can be identified within the genome. Molecular markers are used in molecular biology and biotechnology to identify a particular sequence of DNA in a pool of unknown DNA. As a result of genetic alterations (insertions, deletions, mutations), the base composition at a particular location of the genome may be different in different individuals. These differences, collectively called as polymorphisms can be mapped and identified. A common objective of molecular genetics analysis is to diagnose the differences among presumed stocks in either nuclear allelic types or mtDNA haplotypes (Danzmann and Ihssen, 1995). Use of DNA markers in population genetic studies of rohu is limited to allozyme (Rana et al., 2004) and mtDNA (Luhariya et al., 2012). Nowadays, microsatellites have become the marker of choice for application in fish population genetic studies (Beckmann and Soller, 1990) and can be used to detect genetic introgression in a species. Microsatellites were detected in eukaryote genomes about thirty years ago and since then they are the most promising PCR-based markers. They are tandemly repeated nucleotide sequences of variable lengths that are distributed all over the eukaryotic nuclear genome in both coding and non-coding regions (Jarne and Lagoda, 1996). Owing to the high mutation rate of microsatellites, they are potentially the most edifying molecular marker with the advantage of easy and low-cost detection by PCR. They were found to be informative in several species which showed almost no variation at other markers (Taylor et al., 1994). This is the reason they have become the markers of choice for a wide range of applications in population genetic, conservation and evolutionary biology and represent ideal molecular markers because they have multiple alleles which are highly polymorphic among individuals (Mojekwu and Anumudu, 2013). Therefore, the aim of present study was to assess the level of intra and inter population 
genetic variation among the two populations of Labeo rohita collected from two zoned of River Ganga using microsatellite DNA markers.

\section{Materials and Methods}

\section{Experimental fish and sites}

Experiment was conducted to access the level of polymorphism and genetic diversity in natural population of Labeo rohita collected from selected zones of River Ganga (Haridwar region for upper zone and Kanpur for middle zone). Thirty samples of $L$. rohita were collected from commercial hauls of each sampling site. Fin tissues were cut with help of sharp and clean scissor, immediately put in sampling tubes containing $90 \%$ chilled ethanol, labelled and transferred to the laboratory. Total genomic DNA was isolated from collected fin clips of each fish sample using HiPurA Genomic DNA Purification Kit (HiMedia) with some modifications in the protocol. Quality and Quantity of DNA was also checked.

\section{Microsatellite primers and amplification}

10 microsatellite primers were designed (Table 1) using Primer-BLAST and Primer-3 software's and synthesised by Eurofins Genomics, India. All the microsatellite primers were screened in duplicate DNA samples of fishes collected from two sites. 5 out of 10 primers were successfully screened and produced amplicons and were selected for further analysis. PCR amplifications of microsatellite loci were performed in a $25 \mu \mathrm{l}$ reaction mixture, which included $50 \mathrm{ng}$ template DNA, 5 pmol of each forward and reverse primer, $12.5 \mu \mathrm{l}$ of $2 \mathrm{X}$ PCR master mix solution and remaining volume of molecular biology grade water to make up the volume $25 \mu$ l. Protocol for PCR amplification was also standardized consisting of initial denaturation at $94^{\circ} \mathrm{C}$ for 3 minutes; followed by 35 cycles of $94^{\circ} \mathrm{C}$ for 30 seconds (denaturation), annealing at different annealing temperature (depending on the respective primer pairs) for 60 seconds, 90 seconds at $72^{\circ} \mathrm{C}$ (extension); and a final extension for 8 minutes at $72^{\circ} \mathrm{C}$. Amplified products were mixed with required volume of gel loading buffer and separated on $1.5 \%$ ultra-resolution agarose gel with $1 \mathrm{X}$ TAE buffer on horizontal electrophoresis unit with a constant power supply of 50 volts for $2 \mathrm{hrs}$. After separation, the gel was visualized on a UV transilluminator of gel documentation unit.

\section{Scoring of bands}

All gels images were scored manually for the bands representing particular alleles at the microsatellite loci. Bands representing particular alleles at the microsatellite loci were scored from the plate and the size of the bands was estimated using the software AlphaImager against 100bp DNA ladder. Scoring of genotypes for a specific locus was performed on the basis of number of alleles of a particular size present in that locus.

\section{Analysis of data}

The genotypic data of each locus was subjected to rigorous analysis to calculate allele frequency (A), expected heterozygosity $\left(\mathrm{H}_{\mathrm{e}}\right)$ observed heterozygosity $\left(\mathrm{H}_{\mathrm{o}}\right)$, Shannon's information index (SI) and inbreeding coefficient $\left(\mathrm{F}_{\mathrm{is}}\right)$ to find out the genetic profile collected samples of Labeo rohita. Nei's average expected genetic diversity $\left(\mathrm{H}_{\mathrm{i}}\right)$ was also calculated as it is a measurement of genetic variation for randomly mating populations and is analogous to the average heterozygosity. Software POPGENE Version 1.32 (Yeh et al., 1999) was used to analyze allele frequency and heterozygosity and inbreeding coefficient. Polymorphic 
information content (PIC) was also estimated which provides an estimate of the discriminatory power of a locus or loci, by taking into account, not only the number of alleles that are expressed, but also relative frequencies of those alleles.

\section{Results and Discussion}

Primers amplification results of Labeo rohita collected from Haridwar zone of River Ganga

In Labeo rohita samples collected from Haridwar zone of River Ganga five microsatellite primers were successfully amplified and showed polymorphism. Number of alleles per locus ranged from 4-9 with mean value of 6.8 per locus. A total of 4 SSR loci were scored by the primer LR-02. The product size ranged from $0.15 \mathrm{~Kb}$ to 0.39 $\mathrm{Kb}$ and the PIC value of the primer was 0.66 . A total number of 9 SSR loci were scored by the primer LR-03. The product size ranged from $0.11 \mathrm{~Kb}$ to $0.98 \mathrm{~Kb}$ and the PIC value of the primer was 0.71 . The totals of 8 SSR loci were scored for the primer LR-05 with product size ranged from 0.16 to $0.71 \mathrm{~Kb}$ and the PIC value of the primer was 0.76 . The total of 8 SSR polymorphic loci was scored for the primer LR-06. The product size ranged from $0.11 \mathrm{~Kb}$ to $0.92 \mathrm{~Kb}$ and the PIC value of the primer was 0.69 . Total numbers of 5 SSR loci were scored by the primer LR-07 and all the loci were found to be polymorphic. The product size ranged from $0.10 \mathrm{~Kb}$ to 0.47 and the PIC value of the primer was 0.76 (Table 2).

Primers amplification results of Labeo rohita collected from Kanpur zone of River Ganga

In Labeo rohita samples collected from Kanpur zone of River Ganga five microsatellite primers were successfully amplified and showed polymorphism Number of alleles per locus ranged from 4-9 with mean value of 6.4 per locus (Table 3). A total of 4 SSR loci were scored by the primer LR-02. The product size ranged from $0.13 \mathrm{~Kb}$ to $0.35 \mathrm{~Kb}$ and the PIC value of the primer was 0.64 . A total number of 7 SSR loci were scored by the primer LR-03. The product size ranged from $0.13 \mathrm{~Kb}$ to $0.92 \mathrm{~Kb}$ and the PIC value of the primer was 0.69 . The totals of 7 SSR loci were scored for the primer LR-05 with product size ranged from 0.16 to 0.73 $\mathrm{Kb}$. and the PIC value of the primer was 0.72 . The total of 9 SSR polymorphic loci was scored for the primer LR-06. The product size ranged from $0.11 \mathrm{~Kb}$ to $0.90 \mathrm{~Kb}$ and the PIC value of the primer was 0.71 . Total numbers of 5 SSR loci were scored by the primer LR07 and all the loci were found to be polymorphic. The product size ranged from $0.10 \mathrm{~Kb}$ to 0.51 and the PIC value of the primer was 0.73 .

\section{Microsatellite based genetic variations between the populations}

High levels of polymorphism of five microsatellite markers were observed for both population of Labeo rohita as given in tables 4 and 5 . The average observed heterozygosity was found to be higher than the average expected heterozygosity in the fish samples collected from both Haridwar zone and Kanpur zone of River Ganga. According to Allendorf and Utter, (1979), the best estimate of genetic variation in natural population is the mean observed heterozygosity per locus which varies non- randomly between loci, populations and species. In the present study, the observed heterozygosity values were found to be ranging from 0.7086 (at LR-02) to 0.7543 (at LR-05) with average value of 0.7223 in relation to the expected heterozygosity value ranging from 0.6871 (at LR-02) to 0.7391 (at LR-05) with average value of 0.7126 in fish samples collected form 
Haridwar zone of River Ganga. In Kanpur zone of River Ganga the observed heterozygosity values were found to be ranging from 0.6791 (at LR-06) to 0.7183 (at LR-05) with average value of 0.6927 in relation to the expected heterozygosity value ranging from 0.6524 (at LR-02) to 0.7102 (at LR-03) with average value of 0.6887 .

The value of Nei's genetic diversity in the population of Labeo rohita from Haridwar zone of River Ganga was found to be ranging from 0.712 to 0.868 with average value of 0.764 whereas in the population of Labeo rohita from Kanpur zone of River Ganga the values ranged from 0.677 to 0.741 with the average of 0.715 . The mean value of Shannon's Information Index was found to be 1.4775 in the population from Haridwar zone and 1.4418 in the population from Kanpur zone of River Ganga. The $F_{I S}$ value was found to be negative at all loci in the population from Haridwar zone. The F $F_{\text {IS }}$ value (in '-ve') ranged from 0.103 to 0.031 with average of
0.077. For Kanpur zone, the mean $\mathrm{F}_{\text {IS }}$ value was 0.008 (in '-ve'), ranging from -0.038 to +0.029 .

High level of genetic diversity in the samples of Labeo rohita obtained from Haridwar and Kanpur region of River Ganga is well supported and confirmed by the findings of Sahoo et al., (2014) where high level of genetic diversity in the populations of peninsular Labeo rohita was detected by eleven microsatellite loci as evident from high level of heterozygosity (0.0500-0.847) and large number of alleles per locus (4-23). Similar results were also observed by Swain et al., (2013) when they used three polymorphic microsatellite loci for genetic diversity analysis of three populations of Labeo fimbriatus from three different rivers of Southern India and found that for each population the expected heterozygosity was lower than the observed heterozygosity leading to negative inbreeding coefficient $\left(\mathrm{F}_{\mathrm{IS}}\right)$ indicating excessive heterozygosity.

Table.1 List of designed microsatellite primers and their annealing temperature

\begin{tabular}{|c|c|l|c|c|}
\hline S. No. & Locus & \multicolumn{1}{|c|}{ Primer Sequence } & \multicolumn{1}{c|}{$\begin{array}{c}\text { Repeat } \\
\text { type }\end{array}$} & $\mathbf{T}_{\mathbf{a}}$ \\
\hline 1 & DJ-LR-1 & $\begin{array}{l}\text { F-GGGTGTGGGAGAGAAAGAGAG } \\
\text { R-GGAGTCTGACAAATGCAGCAAG }\end{array}$ & $(\mathrm{AG})_{52}$ & $59^{\circ} \mathrm{C}$ \\
\hline 2 & DJ-LR-2 & $\begin{array}{l}\text { F-TCTCAGTGGGTGTCATTACCTG } \\
\text { R-CCCATCAAACCATCTCTCTAGCW }\end{array}$ & $(\mathrm{GA})_{27}$ & $59^{\circ} \mathrm{C}$ \\
\hline 3 & DJ-LR-3 & $\begin{array}{l}\text { F-CTGACACTCTTATCTCGCTGCC } \\
\text { R-GACCTGAGCAAACAAACCTCAT }\end{array}$ & $(\mathrm{CT})_{20}$ & $57^{\circ} \mathrm{C}$ \\
\hline 4 & DJ-LR-4 & $\begin{array}{l}\text { F-TCTCTCTTTGTCTTTCCCCTTG } \\
\text { R-CACAAGCCACTGTTTAGCTTCA }\end{array}$ & $(\mathrm{CA})_{17}$ & $55^{\circ} \mathrm{C}$ \\
\hline 5 & DJ-LR-5 & $\begin{array}{l}\text { F-CAAATCTGTGAACATGCAAGC } \\
\text { R-CCTAGTCCCACTCTAGTCAGCA }\end{array}$ & $(\mathrm{AC})_{13}$ & $54^{\circ} \mathrm{C}$ \\
\hline 6 & DJ-LR-6 & $\begin{array}{l}\text { F-AGATAAGACCCTTCTTCCTCGG } \\
\text { R-TTTATTAGGGAGCGTCGAGTG }\end{array}$ & $(\mathrm{CA})_{23}$ & $55^{\circ} \mathrm{C}$ \\
\hline 8 & DJ-LR-7 & $\begin{array}{l}\text { F-CTGTTGGTGACTGTAGGGTGAA } \\
\text { R-GAGAACTCGGTTTGAACATGC }\end{array}$ & $(\mathrm{TG})_{13}$ & $55^{\circ} \mathrm{C}$ \\
\hline 9 & DJ-LR-8 & $\begin{array}{l}\text { F-ACAGTAATCTTGTGTCTGTCTCTCTC } \\
\text { R-GTCTAAACGTGTCTGAGCTGTG }\end{array}$ & $\begin{array}{l}\text { F-TGAATGTTTCCAGTCACCACAT } \\
\text { R-GTAATGCAGCGGAGAATAAACC }\end{array}$ & $57^{\circ} \mathrm{C}$ \\
\hline 10 & DJ-LR-10 & $\begin{array}{l}\text { F-ACAATTCCTGTGTCAACTGTGC } \\
\text { R-TACCGTCTCAGTCTCTTTTCGG }\end{array}$ & $(\mathrm{TG})_{16}$ & $58^{\circ} \mathrm{C}$ \\
\hline
\end{tabular}


Table.2 Screened SSR primer amplification results of Labeo rohita collected from Haridwar zone of River Ganga

\begin{tabular}{|c|c|c|c|}
\hline Locus & $\begin{array}{c}\text { Amplified Product } \\
(\mathbf{K b})\end{array}$ & $\begin{array}{c}\text { Number } \\
\text { of alleles }\end{array}$ & (PIC) \\
\hline LR-02 & $0.15-0.39$ & 4 & 0.66 \\
\hline LR-03 & $0.11-0.98$ & 9 & 0.71 \\
\hline LR-05 & $0.16-0.71$ & 8 & 0.76 \\
\hline LR-06 & $0.11-0.92$ & 8 & 0.69 \\
\hline LR-07 & $0.10-0.47$ & 5 & 0.76 \\
\hline
\end{tabular}

Table.3 Screened SSR primer amplification results of Labeo rohita collected from Kanpur zone of River Ganga

\begin{tabular}{|c|c|c|c|}
\hline Locus & $\begin{array}{c}\text { Amplified Product } \\
(\mathbf{K b})\end{array}$ & $\begin{array}{c}\text { Number } \\
\text { of alleles }\end{array}$ & (PIC) \\
\hline LR-02 & $0.13-0.35$ & 4 & 0.64 \\
\hline LR-03 & $0.13-0.92$ & 7 & 0.69 \\
\hline LR-05 & $0.16-0.73$ & 7 & 0.72 \\
\hline LR-06 & $0.11-0.90$ & 9 & 0.71 \\
\hline LR-07 & $0.10-0.51$ & 5 & 0.73 \\
\hline
\end{tabular}

Table. 4 Genetic diversity of Labeo rohita collected from Haridwar zone of River Ganga through Microsatellite markers

\begin{tabular}{|c|c|c|c|c|c|}
\hline Locus & $\begin{array}{c}\text { Observed } \\
\text { Heterozygosity } \\
\left(\mathbf{H}_{\mathbf{o}}\right)\end{array}$ & $\begin{array}{c}\text { Expected } \\
\text { Heterozygosity } \\
\left(\mathbf{H}_{\mathbf{e}}\right)\end{array}$ & $\begin{array}{c}\text { Nei's } \\
\text { genetic } \\
\text { Diversity } \\
\left(\mathbf{H}_{\mathbf{i}}\right)\end{array}$ & $\begin{array}{c}\text { Shannon's } \\
\text { Information } \\
\text { Index }\end{array}$ & $\begin{array}{c}\text { Fixation } \\
\text { Index } \\
\left(\mathbf{F}_{\text {IS }}\right)\end{array}$ \\
\hline LR-02 & 0.7086 & 0.6871 & 0.712 & 1.4495 & -0.091 \\
\hline LR-03 & 0.7351 & 0.7189 & 0.746 & 1.4649 & -0.062 \\
\hline LR-05 & 0.7543 & 0.7391 & 0.868 & 1.5631 & -0.099 \\
\hline LR-06 & 0.7289 & 0.7085 & 0.723 & 1.5128 & -0.031 \\
\hline LR-07 & 0.7156 & 0.7092 & 0.769 & 1.3971 & -0.103 \\
\hline Mean & $\mathbf{0 . 7 2 2 3}$ & $\mathbf{0 . 7 1 2 6}$ & $\mathbf{0 . 7 6 4}$ & $\mathbf{1 . 4 7 7 5}$ & $\mathbf{- 0 . 0 7 7}$ \\
\hline
\end{tabular}

Table.5 Genetic diversity of Labeo rohita collected from Kanpur zone of River Ganga through Microsatellite markers

\begin{tabular}{|c|c|c|c|c|c|}
\hline Locus & $\begin{array}{c}\text { Observed } \\
\text { Heterozygosity } \\
\left(\mathbf{H}_{\mathbf{0}}\right)\end{array}$ & $\begin{array}{c}\text { Expected } \\
\text { Heterozygosity } \\
\left.\mathbf{( H}_{\mathbf{e}}\right)\end{array}$ & $\begin{array}{c}\text { Nei's } \\
\text { genetic } \\
\text { Diversity } \\
\left(\mathbf{H}_{\mathbf{i}}\right)\end{array}$ & $\begin{array}{c}\text { Shannon's } \\
\text { Information } \\
\text { Index }\end{array}$ & $\begin{array}{c}\text { Fixation } \\
\text { Index } \\
\left(\mathbf{F}_{\text {IS }}\right)\end{array}$ \\
\hline LR-02 & 0.6874 & 0.6524 & 0.677 & 1.4136 & -0.026 \\
\hline LR-03 & 0.6938 & 0.7102 & 0.741 & 1.5298 & 0.017 \\
\hline LR-05 & 0.7183 & 0.6995 & 0.724 & 1.4218 & -0.038 \\
\hline LR-06 & 0.6791 & 0.6922 & 0.726 & 1.4872 & 0.029 \\
\hline LR-07 & 0.7063 & 0.6894 & 0.709 & 1.3564 & -0.022 \\
\hline Mean & $\mathbf{0 . 6 9 2 7}$ & $\mathbf{0 . 6 8 8 7}$ & $\mathbf{0 . 7 1 5}$ & $\mathbf{1 . 4 4 1 8}$ & $\mathbf{- 0 . 0 0 8}$ \\
\hline
\end{tabular}


In the present study, considerable genetic variations among Labeo rohita samples collected from two different regions of River Ganga might be explained through the findings of Singh et al., (2012) where variations in nine polymorphic microsatellite loci was observed on the samples of $L$. calbasu collected from twelve riverine sites indicating considerable variation in the allelic frequencies at all loci in all populations and conclusive evidence about the distinct population substructure and gene pool of L. calbasu in different rivers in India. Ceyhun et al., (2013) also analysed the genetic variation in five different natural populations of brown trout using ten microsatellite markers and found that the mean observed heterozygosity was lower than the mean expected heterozygosity with $\mathrm{F}_{\mathrm{IS}}$ to be negative.

The present findings contradict the findings of Alam et al., (2009) where they used four microsatellite loci for population genetic analysis of Labeo rohita samples from three rivers of Bangladesh and found observed heterozygosity to be less than expected heterozygosity with positive inbreeding coefficient which was correlated with the reduction in population size due to overexploitation, contamination of gene pool through introgression, bottleneck effect, habitat degradation, environmental pollution, etc..

But earlier, using same loci, Das et al., (2005) found the observed heterozygosity to be higher than expected heterozygosity in the Indian population of $L$. rohita which is in accordance to the present findings and these results can be due to the fact that several evolutionary forces like random genetic drift, migration, mutation and their mutual interactions act on the wild populations and influence the pattern of genetic differentiation (Avise, 1994). Charlesworth and Charlesworth, (2016) also suggested that the polymorphism present in natural populations differs markedly in different species and also within the species.

Heterozygosity is an important index for assessing population variation at the genetic level. According to Bao et al., (2007) $\mathrm{H}_{\mathrm{o}}$ is easily influenced by sample sizes, while $\mathrm{H}_{\mathrm{e}}$ can better reflect genetic diversity. Qin et al., (2013) also showed that the average expected heterozygosity was high (0.77) in wild samples of $P$. argenteus revealing a high level of genetic diversity in the specie. Similar results were also shown by Brinez et al., (2011) in six populations of red hybrid tilapia, Nasren et al., (2009) in four natural populations of Heteropneustes fossilis, Antoro et al., (2006) in orange spotted grouper, Epinephelus coioides, inhabiting coastal reefs from western Indian Ocean to western Pacific Ocean using four polymorphic microsatellite markers, Li et al., (2007) using 30 microsatellite markers in six wild populations of common carp (Cyprinus carpio), Kathirvelpandian et al., (2014) in four populations of golden anchovy (Coilia dussumieri).

The present study reveals the similar genetic pattern in terms of average heterozygosity levels as investigations done by Drinan, et al., (2011) using 20 microsatellites for determining the patterns of population genetic variation in westlope cutthroat trout, Oncorhynchus clarkia lewisii, in 25 populations from four rivers revealing a high level of average genetic diversity in the populations. These results can also be confirmed by the observations made by Coimbra et al., in 2017, where microsatellite markers were used for assessment of genetic diversity in four indigenous Sao Francisco River populations of Prochilodus argenteus and found that average observed heterozygosity was higher than the average expected heterozygosity in all the populations and genetic structure analysis revealed that all the four populations shared similar genetic patterns. the present study is the indicative of the fact that the stock of L. rohita of Haridwar region of River Ganga is more genetically diverse and genetically differentiated as compared to the stock of Kanpur region as these sites are distantly located and having negligible chance of exchange of gene pool with each other which is responsible for weak sub-structuring of stocks. Genetic variation observed between the two 
riverine sites may also be caused due to high level of anthropogenic activities in Kanpur region thereby causing blockage of fish movement as well destruction of breeding grounds thus hampering the proper mating within the population and also reducing effective population size.

\section{References}

Alam, M.S., Jahan, M., Hossain, M.M. and Islam, M.S. 2009. Population genetic structure of three major river populations of rohu, Labeo rohita (Cyprinidae: Cypriniformes) using microsatellite DNA markers. Genes \& Genomics, 31(1): 4351.

Allendorf, F.W. and Utter, F.M. 1979. Population genetics. In W.S.Hoar and D.J.Randall (Eds.) Fish Physiology Academic press, New York. 8.

Antoro, S., Na-Nakorn, U. and Koedprang, W., 2006. Study of genetic diversity of orange-spotted grouper, Epinephelus coioides, from Thailand and Indonesia using microsatellite markers. Marine Biotechnology, 8(1): 17-26.

Ashley, M.V., Willson, M.F., Pergams, O.R., O'Dowd, D.J., Gende, S.M. and Brown, J.S., 2003. Evolutionarily enlightened management. Biological Conservation, 111(2): 115-123.

Avise, J.C. 1994. Molecular markers, natural history and evolution, 1st edn. Chappman and Hall, New York, USA, 551 pp.

Banerjee, T., Raj, K.D. and Misra, V. 2008. Conservation of natural fish population. In Proceedings of Taal 2007: The 12th World Lake Conference, 562, p. 567.

Bao, W.B., Shu, J.T., Xu, S.H. and Li, H.F. 2007. Effects of sample size and sex ratio on various genetic diversity measures with microsatellite markers. Chi. J. Ani. Sci. 43: 6-9.

Beckmann, J.S. and Soller, M. 1990. Toward a unified approach to genetic mapping of eukaryotes based on sequence tagged microsatellite sites. Bio/Technology, 8: 930-932.
Briñez, R., Caraballo, O. and Salazar, V. 2011. Genetic diversity of six populations of red hybrid tilapia, using microsatellites genetic markers. Revista MVZ Córdoba, 16(2): 2491-2498.

Ceyhun, S.B. and Çiltaş, A., 2013. Determination of genetic variations of five different indigenous trout species in turkey (Salmo trutta sp. L.) by microsatellite markers. Turkish Journal of Fisheries and Aquatic Sciences, 13: 785793.

Charlesworth, B. and Charlesworth, D., 2016. Population genetics from 1966 to 2016. Heredity.

Coimbra, M.R., Lima, A.P., Oliveira, K.K. and Severi, W. 2017. Microsatellite assessment of the genetic diversity in indigenous populations of curimba (Prochilodus argenteus) in the São Francisco River (Brazil). Conservation Genetics, 1-11.

Danzmann, R.G. and Ihssen, P.E. 1995. Aphylogeographic survey of brook charr (Salvelinus fontinalis) in Algonquin Park, Ontario based upon mitochondrial DNA variation. Molecular Ecology, 4(6): 681697.

Das, P., Barat, A., Meher, P.K., Ray, P.P. and Majumdar, D., 2005. Isolation and characterization of polymorphic microsatellites in Labeo rohita and their cross- species amplification in related species. Molecular ecology notes, 5(2): 231-233.

Drinan, D.P., Kalinowski, S.T., Vu, N.V., Shepard, B.B., Muhlfeld, C.C. and Campbell, M.R. 2011. Genetic variation in westslope cutthroat trout Oncorhynchus clarkii lewisi: implications for conservation. Conservation Genetics, 12(6): 1513- 1523.

Jarne, P. and Lagoda, P.J.L. 1996. Microsatellites from molecules to populations and back. Trends in Ecology \& Evolution, 11(10): 424-429.

Kathirvelpandian, A., Gopalakrishnan, A., Lakra, W.S., Krishna, G., Sharma, R., Musammilu, K.K., Basheer, V.S. and 
Jena, J.K. 2014. Microsatellite markers to determine population genetic structure in the golden anchovy, Coilia dussumieri. Biochemical genetics, 52(5-6): 296-309.

Li, D., Kang, D., Yin, Q., Sun, X. and Liang, L., 2007. Microsatellite DNA marker analysis of genetic diversity in wild common carp (Cyprinus carpio L.) populations. Journal of genetics and Genomics, 34(11): 984-993.

Luhariya, R.K., Lal, K.K., Singh, R.K., Mohindra, V., Punia, P., Chauhan, U.K., Gupta, A., Lakra, W.S., 2012. Genetic divergence in wild population of Labeo rohita (Hamilton, 1822) from nine Indian rivers, analyzed through MtDNA cytochrome b region. Mol. Biol. Rep., 4: 3659-3665.

Mojekwu, T.O and Anumudu, C.I. 2013. Microsatellite markers in Aquaculture: Application in fish population genetics. IOSR Journal of Environmental Science, Toxicology and Food Technology, 5(4): 43-48

Nasren, S., Islam, M.N., Khan, M.G.Q., Islam, M.S. and Alam, M.S., 2009. Genetic variation and differentiation in the Stinging catfish, Heteropneustes fossilis (Bloch), populations assessed by heterologous microsatellite DNA markers.

Qin, Y., Shi, G. and Sun, Y., 2013. Evaluation of genetic diversity in Pampus argenteus using SSR markers. Genet. Mol. Res, 12: 5833-5841.

Rana, R.S., Bhat, K.V., Lakhanpal, S., Lakra, W.S., 2004. Comparative genetic diversity in natural and hatchery populations of indian major carps $(C$. catla and L. rohita). Asian Austral. J. Anim. Sci., 17: 1197-1203.

Sahoo, L., Sahu, B.P., Das, S.P., Swain, S.K., Bej, D., Patel, A., Jayasankar, P. and Das, P., 2014. Limited genetic differentiation in Labeo rohita (Hamilton 1822) populations as revealed by microsatellite markers. Biochemical Systematics and Ecology, 57: 427-431.

Singh, R.K., Lal, K.K., Mohindra, V., Punia, P., Sah, R.S., Kumar, R., Gupta, A., Das, R., Lakra, W.S. and Ayyappan, S., 2012. Genetic diversity of Indian Major Carp, Labeo calbasu (Hamilton, 1822) populations inferred from microsatellite loci. Biochemical Systematics and Ecology, 44: 307-316.

Swain, S., Das, S.P., Bej, D., Patel, A., Jayasankar, P., Chaudhary, B.K., Jena, J.K., Routray, P., Swain, S.K., Das, P.C. and Lakra, W.S., 2013. Evaluation of genetic variation in Labeo fimbriatus (Bloch, 1795) populations using heterologous primers. Indian $J$ Fish, 60(1): 29-35.

Swaminathan, M.S., 1984. In: Chopra, V.L., Joshi, B.C., Sharma, R.P., Bansal, H.C. (Eds.), 1984. Genetics, New Frontiers, 1. Oxford and IBH Publishing Co. Ltd., New Delhi.

Talwar, P.K. and Jhingran, A.G., 1991. Inland fishes of India and adjacent countries (2). CRC Press.

Taylor, A.C., Sherwin, W.B. and Wayne, R.K. 1994. Genetic variation of microsatellite loci in a bottlenecked species: The northern hairy-nosed wombat Lasiorhinus krefftii. Molecular Ecology, 3(4): 277290.

\section{How to cite this article:}

Deepak Joshi, Pushpa Lohni and Ram, R.N. 2017. Genetic Diversity Analysis of Labeo rohita (Hamilton, 1822) Collected from Two Zones of River Ganga Using Microsatellite DNA Markers. Int.J.Curr.Microbiol.App.Sci. 6(7): 4139-4147. doi: https://doi.org/10.20546/ijcmas.2017.607.429 